International Journal of Public Finance
E-ISSN: $2548-0499$ DOI: $10.30927 /$ ijpf.325412
Vol./Cilt: 2 | Issue/Sayı: 1 | (2017), pp. $7-26$
journal homepage: http://dergipark.gov.tr/ijpf

\title{
Vergilemede Kanunilik ilkesi Açısından Anayasa'nın 73/4. Maddesi ile Bakanlar Kuruluna Yetki Verilmesinin Değerlendirilmesi
}

\section{Evaluation of the Authority Granted to the Council of Ministers by Article 73/4 of the Constitution in Terms of Legality Principle of Taxation}

\author{
Adnan GERÇEK ${ }^{1}$

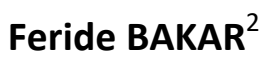

\section{ARTICLE INFO}

Received: 01.07.2017

Received in revised

form: 09.08.2017

Accepted: 10.08.2017

Available online:

15.08.2017

JEL classification: $\mathrm{K} 34, \mathrm{H} 20$

\section{Keywords:}

Taxation Power, Legality Principle of Taxation, Council of Ministers' Decisions, Delegation of Authority

\begin{abstract}
A B S T R A C T
In accordance with the principle of "no taxation without representation", the "legality principle of taxation" is included in the constitutions of all countries. The authority to amend certain elements of taxation within the minimum and maximum limits set by law has been granted to the Council of Ministers by the special provision in Article 73/4 of the Constitution of the Republic of Turkey. The reasons for this provision are "to prevent the exemption of tax burden and exceptions from falling with increasing proportions" and "bringing flexibility and promptness for economic intervention to be effective and fast".

The numbers of regulations on the authorization of the Council of Ministers in Turkish tax laws are increasing day by day. The Council has been granted the authority to amend 107 different articles of 25 tax laws in recent legislation. However, the granted authority in 25 of these articles has never been used until now. During the period 1971-2017, the Council of Ministers used this authority by 735 Decisions. The authority to make amendments to the Council of Ministers; were used 10 times in the "exemption", 22 times in the "exception", 36 times in the "discount", 438 times in the "rate", 195 times in the "fixed amount" and 48 times in the "other" elements of tax respectively.

It is expected that there will be a decrease in the number of new regulations of the Council of Ministers due to decline in inflation after 2003 in Turkey, but in practice the Council has been granted the authority to amend new 32 different articles. However, in a country that has embraced democracy and the rule of law, no provision which may cause deviations from the "legality principle of taxation" can be accepted. For this reason, articles authorizing the Council of Ministers should be removed from the Constitution, which damages the rule of law and legality principle of taxation.
\end{abstract}

\footnotetext{
${ }^{1}$ Prof. Dr., Uludağ Üniversitesi IïBF Maliye Bölümü, agercek@uludag.edu.tr

${ }^{2}$ Araş. Gör., Uludağ Üniversitesi iỉBF Maliye Bölümü, feridebakar@uludag.edu.tr
} 


\section{MAKALE BiLGISi}

Alındı: 01.07.2017

Gözden geçirilmiş

alındı: 09.08.2017

Kabul: 10.08 .2017

Yayın: 15.08.2017

\section{JEL Kodu:}

$\mathrm{K} 34, \mathrm{H} 2 \mathrm{O}$

\section{Anahtar Kelimeler:}

Vergilendirme yetkisi,

Vergilemede kanunilik

ilkesi, Bakanlar Kurulu

Kararları, Yetki devri

\section{ÖZET}

"Temsilsiz vergi olmaz" prensibine uygun olarak vergilemede kanunilik ilkesine genellikle tüm ülke anayasalarında yer verilmiştir. Türkiye'de de Anayasanın 73/4. maddesindeki özel hükümle, vergilemeye ilişkin belirli unsurlarda ve kanunlarda belirlenen sınırlar içinde değişiklik yapma yetkisi Bakanlar Kuruluna devredilmiştir. Bunun gerekçesi de; "vergi yükünün muaflığı ve istisnaların zamanla artan oranla düşmesini engellemek" ve "ekonomiye etkin ve hızlı müdahale edebilmek için esneklik ve çabukluk getirmek" olarak belirtilmiştir.

Türk vergi kanunlarında Bakanlar Kuruluna yetki verilmesine ilişkin düzenlemelerin sayısı her geçen gün artmaktadır. Bu nedenle bu düzenlemelerin sayısının tam olarak belirlenmesi çok zordur. Tespit edilebildiği kadarıyla 2017 yılı itibariyle 25 vergi kanununun en az 107 farklı maddesinde Bakanlar Kuruluna değişiklik yapma yetkisi verilmiştir. Ancak bu maddelerin 25'inde Bakanlar Kuruluna verilen yetki şu ana kadar hiç kullanılmamışır. 1971-2017 yılları arasında Bakanlar Kurulu kendisine verilen yetkiyi en az 735 kez Bakanlar Kurulu Kararları ile kullanmıştır. Bakanlar Kuruluna verilen değişiklik yapma yetkisi; sırasıyla muaflık unsurunda 10 , istisna unsurunda 22 , indirim unsurunda 36 , oran unsurunda 438, maktu tutarlarda 195 ve diğer unsurlarda 48 defa kullanılmıştır.

Ülkemizde 2003 yılından sonra enflasyonun düşmesiyle birlikte Bakanlar Kuruluna yetki devrine ilişkin yeni yasal düzenlemelerin sayısında azalma olması beklenirken, uygulamada böyle olmamış ve 32 yeni kanun maddesinde düzenleme yapma yetkisinin Bakanlar Kuruluna verildiği görülmüştür.

Demokrasiyi ve hukukun üstünlüğünü benimsemiş bir ülkede "kanunsuz vergi olmaz" ve "temsilsiz vergi olmaz" temel ilkelerinden sapmalara yol açabilecek hiçbir hükmün kabul edilmesi düşünülemez. Bu nedenle ülkemizde hukuk devleti ve vergilemede kanunilik ilkesini zedeleyen, vergilemede istikrar ve belirlilik ilkelerini zedeleyen, hatta ortadan kaldıran Bakanlar Kuruluna yetki devrine yönelik hüküm Anayasa metninden çıkarılmalıdır.

\section{Giriş}

Anayasanın 73/4. maddesindeki özel hükümle, vergilemeye ilişkin belirli unsurlarda, kanunlarda belirlenen sınırlar içinde değişiklik yapma yetkisi Bakanlar Kuruluna verilmiştir. Böyle bir yetki verilmesinin sebepleri ve niteliği belirlendikten sonra, bunun kapsamı ve kullanımının somut bir şekilde incelenmesi Bakanlar Kuruluna yetki verilmesinin "vergilemede kanunilik" ve "temsilsiz vergi olmaz" ilkeleri açısından gerekliliğinin değerlendirilmesi için önemlidir. Bu çalışmanın amacı Anayasa'nın 73/4. maddesi ile Bakanlar Kuruluna verilen yetkinin kullanıldığı durumlar incelenerek kapsamının ortaya konulmasıdır. Ayrıca çeşitli ülke anayasalarında böyle bir yetki devrinin mevcut olup olmadığı karşılaştırılarak ülkemizde Bakanlar Kuruluna yetki devrinin gerekliliğinin tartışılması hedeflenmektedir.

$\mathrm{Bu}$ çerçevede çalışmada önce vergilemede kanunilik ilkesinin anlamı açıklanacak, Bakanlar Kurulu'na yetki verilmesinin sebepleri ile Bakanlar Kurulu Kararlarının niteliği ortaya konulacaktır. Daha sonra da Bakanlar Kurulu'nun 
Anayasa'da öngörülen yetkiyi kullanarak, verginin temel unsurlarını doğrudan etkileyen muaflık, istisna, indirim ve oran ile ilgili kararları ayrıntılı bir şekilde incelenecektir. Nihayetinde günümüz koşullarında ülkemizde Bakanlar Kuruluna vergileme alanında yetki verilmesinin gerekliliği değerlendirilecektir.

\section{Vergilemede Kanunilik illkesinin Anlamı ve Çeşitli Ülkelerde Görünümü}

\subsection{Vergilemede Kanunilik Ilkesinin Anlamı}

Vergilemeye yönelik düzenlemelerin gerek şekli gerek maddi anlamda kanunla yapılmasını sağlayan vergilemede kanunilik ilkesi, "devletin vergilendirme yetkisini genel, soyut, kişisel olmayan ve yasama organı tarafından anayasal usullere uygun olarak çıkartılan kanunlar ile kullanması" (Çağan, 1982: 103) olarak tanımlanabilir, çünkü bu ilke "verginin kanuna uygun ve doğru alınmasını da kapsamaktadır" (Kumrulu, 1979: 151). Bir başka ifade ile vergilemede kanunilik ilkesi idarenin sınırsız güce sahip olamayacağının, vergileme yetkisinin sınırının mükelleflerin hak ve özgürlükleri ile evrensel hukuk normlarına uygun olması gerekliliğinin, vergi istisna ve muaflıklarının yasal çerçevesinin çizilmesinin ve yargısal denetiminin bir gerekçesi olarak ele alınabilir (Thuronyi, 2003: 71).

Vergilemede kanunilik ilkesinin temel çerçevesi mali yük konulması, değiştirilmesi, kaldırıması kapsamında hukuk devletinde anayasal bir güvence sunarken, aynı zamanda vergiden doğan ödev ve yöntem ilişkilerinin de yasal bir alt yapıda işlemesini sağlamaktadır (Kaneti, 2011: 225; Güneş, 2008: 17). Vergilemede kanunilik ilkesi verginin kurucu öğelerini de kapsadığından; verginin konusunun, matrahının, yükümlüsünün, oranının, vergiyi doğuran olayın, ödeme zamanının, muaflık ve istisnaların ve bunların alt ve üst sınırlarının kanunla saptanmasını ve idarenin vergileme sürecine yönelik işlemlerinin kanuna uygunluğunu içermektedir (Öncel, Kumrulu ve Çağan, 2010: 14; Öz, 2004: 111). Böylece bu ilke yürütme organının bağlı yetkisinin kaynağını oluşturarak ve vergi hukuku alanında kanuni idare ilkesinin anlamını somutlaştırarak keyfi ve ölçüsüz uygulamalarının önlenmesini sağlamaktadır (Güneş, 2008: 12, Gerçek, 2006: 9).

Günümüzde vergilemede kanunilik ilkesi ve bunun sonucu olarak ortaya çıkan; belirlilik, kıyas yasağı ve geriye yürümezlik ilkeleri anayasal ve uluslararası bir boyuta kavuşmuştur (Munday, 2003: 452-462). Belirlilik ilkesi gereği vergilendirme yetkisi hukuki esaslara dayanmalı ve verginin temel unsurları kanunla düzenlenerek, keyfi ve muğlak hükümlerden uzak olmalıdır (Özer, 1977: 72).

Vergilemede kanunilik ilkesi, yorum veya benzetme yoluyla vergilemede yeni mükellefiyetler, muaflıklar ve istisnalar yaratılamayacağı noktasında önem arz eden kıyas yasağının da sınırını çizmektedir (Tuncer, 2003: 9; Saygııığlu, 1987: 36). Vergilemede kanunilik ilkesinin tamamlayıcısı niteliğini taşıyan geriye yürümezlik ilkesi, kanunların geçmişte meydana gelen vergiyi doğuran olaylara uygulanmamasını ifade etmektedir (Çağan, 2010: 142). Geriye yürümezlik ilkesinin varlık nedenini oluşturan hukuki güvenlik ve kazanılmış hakların korunması prensibi gereğince, sonra çıkarılan 
aleyhte kanunun; tamamlanmış, kesinleşmiş ve hukuki sonuçları doğmuş olaylara uygulanamayacağı kabul edilmektedir (Yaltı, 2011: 181-182).

\subsection{Başka Ülke Anayasalarında Vergilemede Kanunilik İlkesinin Görünümü}

"Temsilsiz vergi olmaz" prensibi çerçevesinde günümüzdeki anayasal vergileme ilkelerinin en önemlisi olan vergilemede kanunilik ilkesinin temeli atılmıştır. Vergilemede kanunilik ilkesinin anlamı, çağdaş demokratik ülkelerde güçler ayrılığı ilkesi çerçevesinde, vergilendirme yetkisinin halkın temsilcilerinden oluşan yasama organına ait olmasıdır. Buna göre vergilemede kanunilik ilkesi, kural olarak yürütme organına vergileme alanında takdir yetkisi verilmemesi ve keyfi uygulamalara imkan tanınmaması sonucunu doğurur. Bu nedenle "temsilsiz vergi olmaz" ve "kanunsuz vergi olmaz" ilkelerine uygun olarak incelenen hiçbir ülke anayasasında yürütme organına vergilendirme yetkisinin herhangi bir şekilde devrine ilişkin bir hüküm bulunmamaktadır (Gerçek vd., 2014: 111).

Tablo 1. Ülke Anayasalarında Kanunilik Illkesi ve Yetki Devrinin Görünümü

\begin{tabular}{|c|c|c|c|c|c|c|c|}
\hline \multirow[b]{2}{*}{ Ülkeler } & \multirow{2}{*}{ 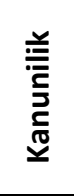 } & \multicolumn{2}{|c|}{$\begin{array}{l}\text { Vergilendirme } \\
\text { Yetkisinin Devri }\end{array}$} & \multirow[b]{2}{*}{ Ülkeler } & \multirow{2}{*}{ 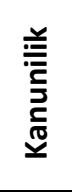 } & \multicolumn{2}{|c|}{$\begin{array}{l}\text { Vergilendirme } \\
\text { Yetkisinin Devri }\end{array}$} \\
\hline & & $\begin{array}{l}\text { Federe } \\
\text { Devlet }\end{array}$ & $\begin{array}{l}\text { Mahalli } \\
\text { İdare }\end{array}$ & & & $\begin{array}{l}\text { Federe } \\
\text { Devlet }\end{array}$ & $\begin{array}{l}\text { Mahalli } \\
\text { İdare }\end{array}$ \\
\hline$A B D$ & Var & Var & Var & Hindistan & Var & Var & Var \\
\hline Almanya & Var & Var & Var & Hırvatistan & Var & - & Var \\
\hline Arjantin & Var & Var & Var & Hollanda & Var & - & Var \\
\hline Avustralya & Var & Var & Var & İspanya & Var & Var & Var \\
\hline Avusturya & Var & Var & Var & İsveç & Var & - & Var \\
\hline Azerbaycan & Var & - & Var & İsviçre & Var & Var & Var \\
\hline Belçika & Var & Var & Var & İtalya & Var & - & Var \\
\hline Brezilya & Var & Var & Var & Japonya & Var & - & - \\
\hline Bulgaristan & Var & - & - & Kanada & Var & Var & Var \\
\hline Çek Cum. & Var & - & - & Kazakistan & Var & - & - \\
\hline Danimarka & Var & - & Var & Polonya & Var & - & Var \\
\hline Endonezya & Var & Var & - & Portekiz & Var & Var & Var \\
\hline Fransa & Var & - & Var & Rusya & Var & Var & Var \\
\hline G. Afrika & Var & Var & Var & TÜRKIYE & Var & $-^{*}$ & - \\
\hline G. Kore & Var & - & - & Yunanistan & Var & - & - \\
\hline
\end{tabular}

* Üniter bir devlet olan Türkiye'de diğer ülkelerden farklı olarak vergilendirme konusunda Bakanlar Kurulu'na şartlı ve sınırlı yetki devri vardır.

Kaynak: Gerçek vd., 2014: 101.

Yukarıdaki tabloda görüldüğü üzere, "kanunsuz vergi olmaz" prensibine uygun olarak vergilemede kanunilik ilkesine incelenen tüm ülke anayasalarında yer verilmiştir. Vergilendirme yetkisinin devri açısından bakıldığında, incelenen ülkelerden federal devlet sistemine sahip on beşinin anayasalarında federe devlete veya yerel hükümete vergilendirme yetkisinin devri ile ilgili hükümlere rastlanmıştır. Yerel yönetimlerin 
özerkliği anlayışına uygun olarak yirmi iki ülke anayasasında ise mahalli idarelere özellikle yerel vergiler koyma ve toplama yetkilerinin verildiği görülmüştür (Gerçek vd., 2014: 102).

Bazı ülkelerde vergilemede kanunilik ilkesinin içeriği vergi matrahı, muafık, istisna, indirim, oran, tahsil biçimlerini kapsayacak şekilde daha spesifik olarak belirlenmiştir (CTPG, 2006: 9). Örneğin Fransa Anayasası md. 34'de "Yasalar, aşağıda belirtilen konulara ilişkin kuralları belirler; ... Her türlü vergilerin matrah, oran ve tahsil biçimleri"; Belçika Anayasası md. 170'de "Devletin menfaatine olan vergiler ancak kanunla konulabilir ... vergilerle ilgili olarak gerekli görülen istisnalar kanunla belirlenir" hükümlerine yer verilmiştir.

Diğer ülkelerde ise vergilemede kanunilik ilkesi genel olarak ifade edilmiştir. Örneğin ABD Anayasası Madde I, Bölüm 8'de "Kongre, aşağıdaki yetkilere sahip olacaktır: Vergi, harç, gümrük, üretim ve tüketim vergisi belirlemek ve toplamak"; Hollanda Anayasası'nın 104. maddesinde "Devletin koyduğu vergiler kanun uyarınca toplanır" hükümlerine yer verilerek vergilerin yasama organı tarafından "kanun" kullanılarak konulacağı belirtilmiştir.

Yerinden yönetim ilkesinin güçlendirilmesi anlayışına uygun olarak birçok ülke anayasasında yerel yönetimlere geniş ölçüde mali özerklik verilmesi ile ilgili düzenlemeler yapılmıştır (Öncel, Kumrulu ve Çağan, 2010: 37-38). Federal devletlerde merkezi yönetim ile federe devletler arasında vergilendirme yetkisinin paylaşımı rutin bir uygulama olduğundan, genellikle bununla ilgili hükümler anayasalarda açıkça düzenlenmiştir. Üniter devletlerde ise vergilendirme yetkisi genellikle merkezi yönetimin elinde toplanmış olup, mahalli idarelere sadece yerel nitelikli bazı vergiler ile ilgili sınırlı yetkiler devredilmiştir (Tavşancı, 2010: 65). Temsilsiz vergi olmaz prensibine uygun olarak, Türkiye hariç, incelenen anayasalarda Bakanlar Kuruluna veya Hükümete vergilendirme yetkisinin herhangi bir şekilde devrine ilişkin bir hükme rastlanmamıştır.

Federal sisteme sahip bazı ülke anayasalarında vergilendirme yetkisinin federe devletlere devri ve bunların sınırları ilgili hükümlere yer verilmiştir. Örneğin Alman Anayasası md. 105/2a'da "Eyaletler, bölgesel federal yasayla düzenlenen vergilerle aynı cinsten olmayan tüketim ve sarf vergileri konusunda yasama yetkisine sahiptirler", Brezilya Anayasası md. 150/VI'da "Herhangi bir vergi istisnası ya da muaflığı, sadece özel bir federal, eyalet veya belediye kanunu ile verilebilir" hükmüne yer verilerek eyaletlere vergilendirme konusunda yetki devri ve sınırları belirlenmiştir.

Diğer taraftan birçok ülke anayasasında özellikle yerel vergiler koyma yetkisinin mahalli idarelere devredildiği görülmektedir. Örneğin Alman Anayasası md. 106'da "Mahalli idareler yasalar çerçevesinde yerel vergiler (emlak vergisi, yerel ticaret vergisi, yerel sanayi vergisi) koyma yetkisine sahiptirler", İsveç Anayasası Bölüm 1 md. 7'de "Yerel idareler kendi işlerinin yönetimi için vergi koyabilirler", Kanada Anayasası md. 92/2'de "ilin amaçları doğrultusunda il idaresi doğrudan vergi koyma yetkisine sahiptir" hükümlerine yer verilerek mahalli idarelerin vergilendirme yetkisi vurgulanmıştır. 


\section{Vergileme Alanında Bakanlar Kurulu'na Yetki Verilmesinin Sebebi ve Niteliği}

Yasama organı, vergilemede kanunilik ilkesi çerçevesinde vergiye ilişkin temel hususları belirledikten sonra, kanunların uygulanmasını sağlamak üzere tekniğe, teferruata ve uzmanlık isteyen hususlara ilişkin konuların düzenlenmesi yürütme organına bırakılmıştır. Anayasanın 73. maddesinin 4. fıkrasındaki özel hükümle, vergilemeye ilişkin belirli konular itibariyle ve kanunların belirttiği sınırlar içinde değişiklik yapma yetkisi Bakanlar Kuruluna verilmiştir. Buna göre, "Vergi, resim, harç ve benzeri malî yükümlülüklerin muaflık, istisnalar ve indirimleriyle oranlarına ilişkin hükümlerinde kanunun belirttiği yukarı ve aşağı sınırlar içinde değişiklik yapmak yetkisi Bakanlar Kuruluna verilebilir".

Vergileme alanında Bakanlar Kuruluna sınırlı da olsa düzenleme yetkisi verilmesinin çeşitli gerekçeleri vardır. Çağdaş demokratik ülkelerde parlamentoların işleyiş usulüne bağlı olarak kanun çıkarmanın zaman alması, özellikle ekonomi alanında gerekli tedbirlerin hızlı ve etkin bir şekilde alınmasını engellediğinden, ülkenin sosyoekonomik dengeleri için zararlı sonuçlar doğurabilir. Oysa yürütme organının toplanması ve çalışmasının, yasama organına göre çok daha hızlı ve kolay olması nedeniyle, günün ihtiyaçlarına göre idarenin ekonomiye çabuk ve etkin müdahale edebilmesini sağlamak için Bakanlar Kuruluna düzenleme yetkisi verilmiştir (Şenyüz, 1999: 20). Yasama sürecinin uzunluğunun yanı sıra, bu süreçte mükelleflerin olumsuz tepkilerinin ortaya çıkması veya baskı gruplarının yasama organını etkilemesi gibi nedenler de, belirli sınırlar içinde düzenleme yetkisinin Bakanlar Kuruluna verilmesine yol açmıştır.

Vergileme alanı ekonomik konjonktüre sıkı sıkıya bağlı bir alan olduğundan, enflasyonun yaratmış olduğu aşınmayı telafi etmek, teknolojik gelişmeleri, yatırımları ve istihdamı kısa dönemde yönlendirmek ve etkilemek için de Bakanlar Kuruluna düzenleme yetkisi verilmiştir (Güneş, 2008: 158). Ayrıca, çerçevesi kanunlarla belirlendikten sonra, vergilendirmeye ilişkin bazı usul ve esaslarla ilgili teknik ve uzmanlaşma gerektiren konularda idareye düzenleme yapma yetkisi verilmesinin esneklik, kolaylık ve uygulanabilirlik sağladığı savunulmuştur (Kaneti, 1989: 39).

Yaşanan bu gelişmeler neticesinde Türk Anayasa Hukukunda 1961 Anayasasının 61. maddesinde 20.09.1971 tarih ve 1488 Sayılı Kanunla (22.09.1971 tarih, 13964 sayılı RG) yapılan Anayasa değişikliğiyle vergilendirme konusunda Bakanlar Kuruluna yetki verilmesine yönelik hüküm hukuk düzenimizde yerini almıştır. Bu değişiklik ile Anayasanın 73/4. maddesi ile vergilemede kanunilik ilkesi bir derece yumuşatılarak Bakanlar Kuruluna verginin temel unsurları üzerinde doğrudan etkili (muaflık, istisna, indirim ve oran) hususlarda değişiklik yapma yetkisi verilmiştir. Buna göre Bakanlar Kurulu, sadece kendisine yetki verilmesi durumunda ve kanunlarla belirlenen sınırlar içinde düzenleme yapabilir. Dolayısıyla, Bakanlar Kuruluna verilen yetki hem şartlı, hem de sınırlıdır. 


\section{Türk Vergi Kanunlarında Bakanlar Kurulu Kararlarının Kapsamı ve Kullanımı}

\subsection{Genel Olarak}

Türk vergi kanunlarında Bakanlar Kuruluna yetki verilmesinin kapsamı ve kullanımının değerlendirilebilmesi için hangi vergi kanununda Bakanlar Kuruluna kaç tane düzenleme yapma yetkisi verildiği ve bunların ne kadarının kullanıldığı incelenmiştir. Vergi kanunları incelenirken, Gümrük Kanunu ile ilgili verilen yetkiler ve bunların kullanımına ilişkin kararlar, gümrük idareleri tarafından alınan vergi, resim ve fonların özel yapısı nedeniyle kapsam dışı bırakılmıştır. Anayasada Bakanlar Kuruluna değişiklik yapma yetkisinin verildiği 1971 yılından günümüze kadar hangi vergi kanununda, hangi konuda ve kaç adet değişiklik yapma yetkisi verildiği tespit edilmeye çalışılmıştır. Ülkemizde vergileme ile ilgili yayınlanan Bakanlar Kurulu Kararlarının tespit edilmesine yönelik sistematik çalışma sayısı çok azdır. Özellikle 1971-1980 tarihleri arasında yayınlanan Bakanlar Kurulu Kararlarına ulaşmak çok zordur. Bu nedenle çalışmada ağırlıklı olarak 1980-2017 yılları arasında çıkarılan kararlar incelenmiş olup, bunların dağılımı aşağıda Tablo 2'de gösterilmiştir.

Tablo 2. Türkiye'de Bakanlar Kuruluna Verilen Değiş̧iklik Yapma Yetkisinin Dağılımı

\begin{tabular}{|l|c|c|c|c|c|}
\hline \multicolumn{1}{|c|}{ Kanun } & $\begin{array}{c}\text { BKK Madde } \\
\text { Sayısı }\end{array}$ & $\begin{array}{c}\text { BKK ve YDO } \\
\text { Madde Sayısı }\end{array}$ & $\begin{array}{c}\text { BKK } \\
\text { Sayısı }\end{array}$ & $\begin{array}{c}\mathbf{2 0 0 2} \text { ve } \\
\text { Öncesi }\end{array}$ & $\begin{array}{c}\mathbf{2 0 0 3} \text { ve } \\
\text { Sonrası }\end{array}$ \\
\hline 6183 Sayılı AATUHK & 6 & 0 & 31 & 23 & 8 \\
\hline Vergi Usul Kanunu & 6 & 3 & 26 & 26 & 0 \\
\hline Gelir Vergisi Kanunu & 24 & 7 & 149 & 133 & 16 \\
\hline Kurumlar Vergisi Kanunu & 18 & 0 & 64 & 40 & 24 \\
\hline KDV Kanunu & 8 & 0 & 114 & 57 & 57 \\
\hline ÖTV Kanunu & 4 & 0 & 116 & 0 & 116 \\
\hline Gider Vergileri K. (BSMV) & 1 & 0 & 23 & 15 & 8 \\
\hline Özel İletişim Vergisi Kanunu & 1 & 1 & 0 & 0 & 0 \\
\hline Damga Vergisi Kanunu & 2 & 1 & 12 & 8 & 4 \\
\hline Emlak Vergisi Kanunu & 7 & 1 & 30 & 24 & 6 \\
\hline Motorlu Taşıllar Vergisi K. & 2 & 1 & 14 & 11 & 3 \\
\hline Veraset ve İntikal Vergisi K. & 2 & 2 & 2 & 2 & 0 \\
\hline Harçlar Kanunu & 2 & 1 & 19 & 12 & 7 \\
\hline Belediye Gelirleri Kanunu & 9 & 1 & 13 & 5 & 8 \\
\hline Akaryakıt Tüketim Vergisi & 3 & 0 & 63 & 63 & 0 \\
\hline Taşıt Alım Vergisi & 2 & 0 & 20 & 20 & 0 \\
\hline Vergi ladesi Kanunu & 1 & 0 & 16 & 16 & 0 \\
\hline Diğer* & 9 & 0 & 23 & 21 & 2 \\
\hline & 107 & 18 & 735 & $\mathbf{4 7 6}$ & $\mathbf{2 5 9}$ \\
\hline
\end{tabular}

*PTT Hizmetleri Vergisi, Gider Vergileri, SSDF, Özel İşlem Vergisi, Gençlik, Spor ve Sağlık Hizmetleri Vergisi, Akaryakıt Fiyat İstikrar Fonu, Yurtdışı Çıkış Harcı Kanunu, 6111 Sayılı Kanun.

Kaynak: Tablo 3, 4, 5, 6 ve 7'den yararlanılarak tarafımızca hazırlanmıştır.

Tablo 2'ye göre, 2017 yılı itibariyle 25 vergi kanununun 107 farklı maddesinde Bakanlar Kuruluna değişiklik yapma yetkisi verilmiştir. Bu maddelerden 89 tanesinde sadece Bakanlar Kuruluna değişiklik yapma yetkisi verilmiş iken, diğer 18 maddede 
Bakanlar Kurulunun yanı sıra Yeniden Değerleme Oranına göre güncelleme yapılması düzenlemesi de bulunmaktadır. Diğer taraftan 2002 yılı ve öncesinde 7 tane maddede Bakanlar Kuruluna değişiklik yapma yetkisi verilmesine rağmen bu yetki hiç kullanılmamıştır. Buna karşılık 2003 yılı ve sonrasında 16 tane maddede Bakanlar Kuruluna değişiklik yapma yetkisi verilmesine rağmen bu yetkinin hiç kullanılmadığı tespit edilmiştir.

Türk vergi kanunlarında Bakanlar Kuruluna yetki verilmesinin temel gerekçesi enflasyonun yaratmış olduğu aşınmayı telafi etmek olduğundan ülkemizde enflasyonun yüksek olduğu ve düşük olduğu dönemlerde yapılan değişiklik sayıları yukarıdaki tabloda karşılaştırmalı olarak incelenmiştir. 1980-2017 yılları arasında Bakanlar Kurulu kendisine verilen yetkiyi 735 kez kullanmıştır. Aslında Bakanlar Kurulu Kararlarının sayısal çokluğu bu verilerden daha fazla olabilir. Diğer taraftan bazı Bakanlar Kurulu Kararları ile vergi kanunlarının birden fazla maddesinde yapılan değişiklikler de sayının artmasına yol açabilir (Kelecioğlu, 2001: 160).

Ülkemizde enflasyon (TÜFE) oranının \%20'nin üzerinde olduğu 2002 yılı ve öncesi ile enflasyon (TÜFE) oranının \%20'nin altında olduğu 2003 yılı ve sonrası iki ayrı dönem olarak ele alınmıştır. Buna göre 2002 yılı ve öncesinde Bakanlar Kurulu kendisine verilen yetkiyi 476 defa, 2003 yılı ve sonrasında ise bu yetkisini 259 defa kullanmıştır. Görüldüğü üzere ülkemizde enflasyon oranının düşmesi ile birlikte Bakanlar Kurulu kendisine verilen yetkiyi daha az kullanma ihtiyacı duymuştur. Özellikle ÖTV ve KDV Kanunları ile ilgili Bakanlar Kurulunun kullandığı yetkiler hariç tutulduğunda bu yetkinin sınırlı sayıda kullanıldığı görülmektedir. Bunun bir sebebi de GVK ve VUK'un birçok maddesinde güncellenmesi gereken had ve tutarların yeniden değerleme oranına bağlanmış olması ve Bakanlar Kurulu kararı yerine güncellemelerin bu orana göre yapılmasıdır.

\subsection{Bakanlar Kurulunun Muaflık ile ilgili Kararları}

Anayasanın 73/4. maddesinde sayılan verginin unsurları açısından Bakanlar Kuruluna değişiklik yapma yetkisi verilmesi incelendiğinde; vergi kanunlarında "muaflık" ile ilgili Bakanlar Kuruluna sadece üç kanunun 4 maddesinde Bakanlar Kuruluna yetki verilmiştir. Bakanlar Kuruluna verilen bu yetkilerin konusu, kanun maddeleri ve kullanılan BKK sayısı aşağıda Tablo 3'de gösterilmiştir.

Tablo 3. "Muaflık" Unsuru İle İlgili Bakanlar Kuruluna Verilen Değişiklik Yapma Yetkisinin Dağılımı

\begin{tabular}{|l|l|l|}
\hline \multicolumn{1}{|c|}{ Konusu } & \multicolumn{1}{|c|}{ Kanun Maddesi } & \multicolumn{1}{c|}{ BKK Sayıs ve Numarası } \\
\hline Muaflıklar & GVK md. 13, 17 & $\begin{array}{l}\text { 8 ADET; 86/11239, 87/11986, 89/14258, } \\
\text { 91/2349, 92/3892, 93/5146, 94/6300, 95/7593 }\end{array}$ \\
\hline Geçici Muaflıklar & EVK md. 15 & 1 ADET; 7/8147 \\
\hline Muaflık & PTT Hizm. Vergisi & 1 ADET; 83/6325 \\
\hline
\end{tabular}

Kaynak: Tablo 1980-1997 yılları arası için Maliye Bakanlığı GGM, 1997'den, 1997-2002 yılları arası için Maliye Bakanlığı GGM, 2002'den ve diğer yıllar için Kazancı Mevzuat Bilgi Bankasından yararlanılarak tarafımızca hazırlanmıştır. 
Yukarıdaki tablodan da görüldüğü gibi iki maddede Bakanlar Kuruluna verilen değişiklik yapma yetkisi sadece birer kez kullanılmıştır. Bir maddedeki yetki ise 8 defa kullanılmış ve göçmen ve mülteci muaflığı ile ilgili tutar belirlenmiştir. Günümüzde Bakanlar Kuruluna muafık ile ilgili değişiklik yapma yetkisi verilen bir kanun hükmü bulunmamaktadır. Ancak Gelir Vergisi Kanunu'nun mük. md. 20'deki Genç Girişimcilerde Kazanç İstisnası ile ilgili düzenleme esas itibariyle mükelleflerin özelliğine yönelik olduğundan muaflık olarak değerlendirilmesi daha doğru olacaktır.

\subsection{Bakanlar Kurulunun İstisna İle İlgili Kararları}

Anayasanın 73/4. maddesinde sayılan verginin diğer bir unsuru olan "istisna" ile ilgili beş vergi kanununun 7 maddesinde Bakanlar Kuruluna yetki verilmiştir. Bakanlar Kuruluna verilen bu yetkilerin konusu, kanun maddeleri ve kullanılan BKK sayısı aşağıda Tablo 3'de gösterilmiştir.

Tablo 3. “istisna” Unsuru Ille İlgili Bakanlar Kuruluna Verilen Değişiklik Yapma Yetkisinin Dağılımı

\begin{tabular}{|c|c|c|}
\hline Konusu & Kanun Maddesi & BKK Sayısı ve Numarası \\
\hline ViV İstisna & ViVK md. 4 & 1 ADET; 1991/1842 \\
\hline Arazi vergisinde istisna tutarı & EVK md.16 & 0 ADET \\
\hline Yatırımlarda istisna haddi & KDVK md.13 & 2 ADET; 2004/7765, 2004/8127 \\
\hline Taşımacılık istisnası & KDVK md.14 & $\begin{array}{l}5 \text { ADET; 2006/10784, 2006/11167, 2006/11453, } \\
2007 / 12574,2011 / 1819\end{array}$ \\
\hline Transit taşımacılık & KDVK md.14 & 1 ADET; $84 / 8889$ \\
\hline Sanayi ürünleri ihracatı & 5422 Eski KVK md. 8 & $\begin{array}{l}5 \text { ADET; 88/13602, 90/328, 91/1534, 91/2073, } \\
\text { 92/3893, }\end{array}$ \\
\hline $\begin{array}{l}\text { KVK Yabancı fon kazançları } \\
\text { istisnası oranı }\end{array}$ & KVK md.5/A & 0 ADET \\
\hline $\begin{array}{l}\text { Sınai mülkiyet haklarında } \\
\text { istisnası oranı }\end{array}$ & KVK md.5/B & 0 ADET \\
\hline $\begin{array}{l}\text { GVK istisna tutarları, maktu had } \\
\text { tutarları }\end{array}$ & GVK mük. md. 123 & $\begin{array}{l}13 \text { ADET; 83/7511, 92/3892, 93/5146, 94/6300, } \\
\text { 95/7593, 96/8955, 97/10351, 2000/1689, } \\
\text { 2001/3398, 2002/5000, 2003/6578, 2004/8295, } \\
2005 / 9826\end{array}$ \\
\hline
\end{tabular}

Kaynak: Tablo 1980-1997 yılları arası için Maliye Bakanlığı GGM, 1997'den, 1997-2002 yılları arası için Maliye Bakanlığı GGM, 2002'den ve diğer yıllar için Kazancı Mevzuat Bilgi Bankasından yararlanılarak tarafımızca hazırlanmıştır.

Yukarıdaki tablodan da görüldüğü gibi üç maddede Bakanlar Kuruluna verilen değişiklik yapma yetkisi henüz hiç kullanılmamıştır. İki maddedeki yetki sadece 1 defa kullanılmış ve daha sonra yeniden değerleme oranı ile güncelleme yapılmıştır. Diğer bir maddedeki yetki bir yıl içinde yatırımlarda istisna haddi belirlemek için 2 defa kullanılmış ve daha sonra hiç kullanılmamıştır. Bir diğer maddedeki yetki ise 5 defa kullanılmış ve bunlarla istisna tanınan gümrük kapıları belirlenmiştir. Bu yetkide Anayasada sayılan unsurlar ve sınırların dışına çıkıldığından, Anayasaya aykırılık söz konusudur. Gelir Vergisi Kanununda istisna tutarlarının belirlenmesi ile ilgili yetki 13 defa kullanılmış ve daha sonraki yıllarda yeniden değerleme oranı ile güncelleme yapılmaya başlanmıştır. 


\section{4. İndirim İle İlgili Bakanlar Kurulu Kararlarının Kullanımı}

Verginin diğer bir unsuru olan "indirim" ile ilgili dört kanunun 13 maddesinde Bakanlar Kuruluna yetki verilmiştir. Bakanlar Kuruluna verilen bu yetkinin konusu, kanun maddeleri ve kullanılan BKK sayısı aşağıda Tablo 4'de gösterilmiştir.

\section{Tablo 4. "Indirim” Unsuru İle İlgili Bakanlar Kuruluna Verilen Değişiklik Yapma Yetkisinin Dağılımı}

\begin{tabular}{|c|c|c|}
\hline Konusu & Kanun Maddesi & BKK Sayısı ve Numarası \\
\hline $\begin{array}{l}\text { Özel İndirim } \\
\text { Sakatlık İndirimi } \\
\text { Engelli İndirimi }\end{array}$ & GVK md. 31 & $\begin{array}{l}14 \text { ADET; 91/1372, 92/3892, 93/5146, 94/6300, 95/7593, } \\
\text { 96/8955, 97/9954, 97/10416, 98/11697, 98/12030, } \\
\text { 99/13645, 2000/1689, 2001/3398, 2002/5000 }\end{array}$ \\
\hline AGI oranı & GVK md. 32 & 0 ADET \\
\hline $\begin{array}{l}\text { Yurtdışında Hizmet Veren } \\
\text { işletmelerde İnd. }\end{array}$ & GVK md. 33 & 0 ADET \\
\hline İşveren BES gider indirimi & GVK md. 40 & 0 ADET \\
\hline KKEG oranı & GVK md. 41 & 1 ADET; 90/1081 \\
\hline $\begin{array}{l}\text { Ücretlerde özel sigorta primi } \\
\text { oranı }\end{array}$ & GVK md. 63 & 1 ADET; $94 / 5371$ \\
\hline $\begin{array}{l}\text { Beyanname özel sigorta primi } \\
\text { oranı }\end{array}$ & GVK md. 89 & 0 ADET \\
\hline $\begin{array}{l}\text { GVK Bağış ve yardım indirimi } \\
\text { oranı }\end{array}$ & GVK md. 89 & 0 ADET \\
\hline $\begin{array}{l}\text { Yurtdışı Hizmet Kazancı } \\
\text { İndirimi }\end{array}$ & GVK md. 89 & 0 ADET \\
\hline Korumalı İşyeri İndirimi & GVK md. 89 & 0 ADET \\
\hline $\begin{array}{l}\text { Bireysel Katılım yatırımcısı } \\
\text { İndirimi }\end{array}$ & GVK geç. md. 82 & 0 ADET \\
\hline $\begin{array}{l}\text { GVK indirim tutarları, maktu } \\
\text { had tutarları }\end{array}$ & GVK mük. md. 123 & $\begin{array}{l}13 \text { ADET; 83/7511, 92/3892, 93/5146, 94/6300, 95/7593, } \\
\text { 96/8955, 97/10351, 2000/1689, 2001/3398, 2002/5000, } \\
\text { 2003/6578, 2004/8295, 2005/9826 }\end{array}$ \\
\hline KDV İndirim Hakkını kaldırma & KDVK md. 36 & 3 ADET; 2007/12143, 2007/13033, 2008/13234 \\
\hline $\begin{array}{l}\text { KVK Bağış ve yardım indirimi } \\
\text { oranı }\end{array}$ & KVK md. 10 & 0 ADET \\
\hline $\begin{array}{l}\text { KVK Yurtdışı Hizmet Kazancı } \\
\text { İndirimi }\end{array}$ & KVK md. 10 & O ADET \\
\hline KVK Korumalı İşyeri İndirimi & KVK md. 10 & 0 ADET \\
\hline $\begin{array}{l}\text { KVK Özkaynaklar Finansman } \\
\text { İndirimi }\end{array}$ & KVK md. 10 & 1 ADET; 2015/7910 \\
\hline $\begin{array}{l}\text { KVK Kabul edilmeyen } \\
\text { indirimler }\end{array}$ & KVK md. 11 & 1 ADET; 90/1081 \\
\hline $\begin{array}{l}\text { KVK Transfer fiyatlandırması } \\
\text { ile ilgili oranlar }\end{array}$ & KVK md. 13 & 2 ADET; 2007/12888, 2008/13490 \\
\hline
\end{tabular}

Kaynak: Tablo 1980-1997 yılları arası için Maliye Bakanlığı GGM, 1997'den, 1997-2002 yılları arası için Maliye Bakanlığı GGM, 2002'den ve diğer yıllar için Kazancı Mevzuat Bilgi Bankasından yararlanılarak tarafımızca hazırlanmıştır.

Yukarıdaki tablodan da görüldüğü gibi altı maddedeki bu yetki hiç kullanılmamıştır. Dört maddedeki yetki sadece 1 defa, birer maddedeki yetki ise sırasıyla 2 ve 3 defa kullanılmıştır. Ayrıca birer maddedeki yetki de sırasıyla 13 ve 14 defa kullanılmıştır. Indirim unsurunda Bakanlar Kuruluna çok sayıda yetki verilmiş olmasına rağmen, bu yetki fazla kullanılmamıştır. Sadece Gelir Vergisi Kanununda 
indirim tutarlarının belirlenmesi ile ilgili yetki 13 ve 14 defa kullanılmış olup, daha sonra da bu tutarlarda yeniden değerleme oranı ile güncelleme yapılmaya başlanmıştır. Dolayısıyla günümüzde artık az sayıdaki madde ile ilgili değişiklikler Bakanlar Kurulu Kararı ile yapıldığından, bunların kanunla değiştirilmesinde hiçbir sakınca bulunmamaktadır.

\subsection{Bakanlar Kurulunun Oran İle İlgili Kararları}

Bakanlar Kuruluna en fazla sayıda yetki devrinin verginin "oran" unsuru ile ilgili kanun maddelerinde yapıldığı tespit edilmiştir. Oran ile ilgili 18 vergi kanununun 36 maddesinde Bakanlar Kuruluna yetki verilmiştir. Bakanlar Kuruluna verilen bu yetkinin konusu, kanun maddeleri ve kullanılan BKK sayısı aşağıda Tablo 5'de gösterilmiştir.

Tablo 5. “Oran” Unsuru ile İlgili Bakanlar Kuruluna Verilen Değişiklik Yapma Yetkisinin Dağılımı

\begin{tabular}{|c|c|c|}
\hline Konusu & Kanun Maddesi & BKK Sayısı ve Numarası \\
\hline Gecikme Zammı & AATUHK md. 51 & $\begin{array}{l}17 \text { ADET; 85/9790, 88/12947, 88/13646, 89/14915, 94/5335, } \\
\text { 95/7138, 96/7798, 98/11331, 2000/7, 2000/1555, 2001/2175, } \\
\text { 2002/3550, 2003/6345, 2005/8551, 2006/10302, 2009/15565, } \\
2010 / 965\end{array}$ \\
\hline $\begin{array}{l}\text { Erken ödemede } \\
\text { indirim }\end{array}$ & $\begin{array}{l}\text { AATUHK md. Ek } \\
1\end{array}$ & 5 ADET; 96/8560, 96/8892, 97/9387, 97/9942, 2003/5699 \\
\hline Nispet & BSMVK md. 33 & $\begin{array}{l}23 \text { ADET; 83/7504, 86/10563, 87/12471, 88/13608, 91/2072, } \\
\text { 91/2563, 92/3901, 93/5095, 94/6299, 95/7594, 96/8952, 97/10021, } \\
\text { 98/11591, 98/11795, 2002/4506, 2004/7131, 2007/12392, } \\
\text { 2008/13459, 2009/15095, 2009/15398, 2010/1182, 2011/1854, } \\
\text { 2012/3241 }\end{array}$ \\
\hline $\begin{array}{l}\text { Özel İletişim vergisi } \\
\text { oranı }\end{array}$ & ÖivK md. 39 & 0 ADET \\
\hline Nispet (Tarife) & ViVK md. 16 & 1 ADET; 1997/10347 \\
\hline Vergi tevkifatı oranı & GVK md. 94 & $\begin{array}{l}\text { 60 ADET; 8/4517, 85/9206, 85/10175, 86/10508, 86/11330, } \\
\text { 87/11565, 87/11812, 87/11987, 87/12388, 87/12478, 88/12567, } \\
\text { 88/12645, 88/12966, 88/13644, 89/13662, 89/14365, 89/14919, } \\
\text { 91/2074, 91/2564, 92/2682, 92/3078, 92/3802, 92/3900, 93/5148, } \\
\text { 94/5255, 94/5307, 95/6429, 95/7137, 95/7593, 96/8635, 96/8955, } \\
\text { 97/9186, 97/10421, 98/11465, 98/11593, 98/11601, 98/11794, } \\
\text { 98/12225, 99/12623, 99/13230, 99/13646, 2000/1689, 2000/1713, } \\
2001 / 2839,2001 / 2847,2002 / 4369,2002 / 5000,2003 / 5590, \\
2003 / 6577,2005 / 9266,2006 / 10731,2006 / 11449,2009 / 14592, \\
2010 / 926,2010 / 1182,2011 / 1854,2012 / 3322,2012 / 3571, \\
2013 / 4552,2013 / 4552\end{array}$ \\
\hline Tevkifat oranı & GVK md. 105 & 4 ADET; 8/5759, 8/5861, 83/7505, 84/7648 \\
\hline Geçici Vergi Oranı & $\begin{array}{l}\text { GVK mük. md. } \\
120\end{array}$ & 2 ADET; 89/13876, 93/5143, \\
\hline Vergi tarifesi & GVK md. 103 & 2 ADET; 99/13645, 2007/13044 \\
\hline & GVK Geçici 67 & 2 ADET; 2008/14272, 2009/14580 \\
\hline $\begin{array}{l}\text { Enflasyon düzelt. } \\
\text { oranlar }\end{array}$ & $\begin{array}{l}\text { VUK mük.md. } \\
298\end{array}$ & 0 ADET \\
\hline $\begin{array}{l}\text { MTV hadleri } \\
\text { belirleme }\end{array}$ & MTVK md. 5 & 2 ADET; 2004/6743, 2004/8327 \\
\hline $\begin{array}{l}\text { DVK nispetlerin } \\
\text { belirlenmesi }\end{array}$ & DVK md. 14 & $\begin{array}{l}7 \text { ADET; 8/181, 94/6035, 99/13142, 2009/15725, 2011/2628, } \\
\text { 2012/4116, 2016/9641 }\end{array}$ \\
\hline
\end{tabular}


A. Gerçek \& F. Bakar / Anayasa'nın 73/4. Maddesi ile Bakanlar Kuruluna Yetki Verilmesi

\begin{tabular}{|c|c|c|}
\hline DVK nispet & DVK mük.md. 30 & 1 ADET; 87/12067 \\
\hline $\begin{array}{l}\text { EVK Arsa Nispet } \\
\text { (Oran) }\end{array}$ & EVK md. 8 & $\begin{array}{l}\text { 22 ADET; 86/10625, 87/11760, 88/12927, 89/14034, 90/171, } \\
\text { 91/1688, 92/2834, 93/4191, 94/5380, 95/6616, 96/7774, 96/9019, } \\
\text { 98/10752, 98/12031, 99/13802, 2000/1695, 2001/3396, 2002/4998, } \\
\text { 2003/6576, 2004/8268, 2005/9827, 2006/11450 }\end{array}$ \\
\hline $\begin{array}{l}\text { EVK Arazi Nispet } \\
\text { (Oran) }\end{array}$ & EVK md. 18 & 0 ADET \\
\hline $\begin{array}{l}\text { İlan ve Reklam V. } \\
\text { Tarife ve Nispet }\end{array}$ & BGK md. 15 & 2 ADET; 2013/5585, 2014/5896 \\
\hline $\begin{array}{l}\text { Eğlence Vergisi } \\
\text { Tarife ve Nispet }\end{array}$ & BGK md. 21 & 4 ADET; 85/10174, 97/10349, 2013/5585, 2014/5896 \\
\hline $\begin{array}{l}\text { Harc. katıma payı } \\
\text { oranı }\end{array}$ & BGK md. 89 & 0 ADET \\
\hline BGK Tarifenin tespiti & BGK md. 96 & 3 ADET; 91/1365, 2013/5585, 2014/5896 \\
\hline KDV Oranı & KDVK md.28 & $\begin{array}{l}86 \text { ADET; 84/8887, 84/8888, 85/8924, 85/9114, 85/9204, 85/9598, } \\
\text { 85/9771, 86/10626, 86/10793, 86/10925, 86/11217, 87/11482, } \\
\text { 87/12068, 87/12469, 88/13036, 88/13383, 88/13601, 89/14255, } \\
89 / 14916,90 / 919,91 / 1855,91 / 2031,91 / 2069,91 / 2545,92 / 2692, \\
\text { 92/3505, 92/3896, 93/4406, 93/4932, 94/5350, 94/5454, 94/5730, } \\
\text { 95/6431, 95/6432, 95/7139, 95/7176, 95/7612, 95/7613, 98/10884, } \\
\text { 98/11328, 98/11467, 99/12519, 99/13648, 2000/867, 2000/1221, } \\
\text { 2000/1693, 2001/2344, 2001/2789, 2001/3173, 2002/4480, } \\
2003 / 5710,2003 / 5557,2003 / 6666,2004 / 6887,2004 / 7666, \\
2004 / 7802,2004 / 8301,2006 / 10138,2006 / 10620,2007 / 12143, \\
2007 / 13033,2008 / 13234,2008 / 13426,2008 / 13902,2008 / 14092, \\
2009 / 14802,2009 / 14812,2009 / 14881,2009 / 15081,2009 / 15200, \\
2009 / 15315,2011 / 2466,2011 / 2604,2012 / 2697,2012 / 2931, \\
2012 / 3594,2012 / 4116,2013 / 4345,2013 / 5595,2013 / 5761, \\
2015 / 7205,2015 / 8353,2016 / 8705,2016 / 8998,2016 / 9153, \\
2016 / 9542\end{array}$ \\
\hline KDV Ek Vergi & KDVK md. 60 & 2 ADET; $91 / 1755,99 / 13649$ \\
\hline ÖTV Oran ve tutar & ÖTVK md.12 & $\begin{array}{l}\text { 101 ADET; 2002/4482, 2002/4675, 2002/4843, 2002/4930, } \\
\text { 2002/4970, 2003/5141, 2003/5147, 2003/5227, 2003/5357, } \\
\text { 2003/5433, 2003/5455, 2003/5549, 2003/5632, 2003/5752, } \\
\text { 2003/5757, 2003/5868, 2003/5950, 2003/6049, 2003/6153, } \\
\text { 2003/6257, 2003/6258, 2003/6288, 2003/6467, 2003/6497, } \\
\text { 2003/6531, 2003/6607, 2003/6645, 2004/6730, 2004/6760, } \\
\text { 2004/6885, 2004/6992, 2004/7069, 2004/7306, 2004/7334, } \\
\text { 2004/7386, 2004/7512, 2004/7549, 2004/7579, 2004/7640, } \\
\text { 2004/7674, 2004/7730, 2004/7792, 2004/7814, 2004/7888, } \\
\text { 2004/7890, 2004/7893, 2004/8021, 2004/8032, 2004/8059, } \\
\text { 2004/8118, 2004/8128, 2004/8187, 2004/8229, 2004/8266, } \\
\text { 2005/8392, 2005/8410, 2005/8414, 2005/8704, 2005/8716, } \\
\text { 2005/9145, 2005/9281, 2005/9795, 2005/9796, 2006/10170, } \\
\text { 2006/10798, 2006/11045, 2006/11202, 2007/11674, 2007/12756, } \\
\text { 2008/13061, 2008/13210, 2008/13762, 2008/13835, 2008/14061, } \\
\text { 2008/14387, 2009/14802, 2009/14882, 2009/15081, 2009/15200, } \\
\text { 2009/15315, 2009/15725, 2010/135, 2010/668, 2010/973, } \\
\text { 2011/1435, 2011/2198, 2011/2304, 2011/2343, 2012/3139, } \\
\text { 2012/3172, 2012/3735, 2012/3792, 2012/4116, 2013/5595, } \\
\text { 2014/6881, 2015/8353, 2016/9153, 2016/9256, 2016/9542, } \\
2016 / 9567\end{array}$ \\
\hline $\begin{array}{l}\text { Eski KVK oran } \\
\text { değişikliği }\end{array}$ & $\begin{array}{l}5422 \text { Eski KVK } \\
\text { md. } 15,24 \\
\text { mük.25, } 40 \text {, geçici } \\
28\end{array}$ & $\begin{array}{l}35 \text { ADET; 8/2507, 84/7608, 84/7826, 85/10178, 86/10380, } \\
\text { 86/10415, 86/10719, 87/11985, 87/12470, 87/12590, 88/13643, } \\
\text { 89/14237, 90/1081, 91/2075, 91/2565, 92/2904, 92/3895, 92/3897, } \\
\text { 93/5141, 93/5147, 94/5256, 94/6007, 96/8638, 97/9027, 97/10418, } \\
\text { 98/11466, 98/11592, 98/11796, 99/13231, 2000/1515, 2000/1712, } \\
\text { 2001/2846, 2001/3107, 2002/4370, 2003/6575, }\end{array}$ \\
\hline
\end{tabular}




\begin{tabular}{|l|l|l|}
\hline $\begin{array}{l}\text { KVK Vergi kesintisi } \\
\text { oranı }\end{array}$ & KVK md.15 & $\begin{array}{l}\text { 9 ADET; 2006/10731, 2006/11447, 2009/14593, 2009/14594, } \\
\text { 2010/1182, 2011/1854, 2012/3141, 2012/3322, 2013/4552 }\end{array}$ \\
\hline $\begin{array}{l}\text { KVK Dar Mük. Vergi } \\
\text { kesintisi }\end{array}$ & KVK md.30 & $\begin{array}{l}\text { 9 ADET; 2006/10731, 2006/11447, 2009/14593, 2009/15022, } \\
\text { 2010/1182, 2011/1854, 2012/3141, 2013/4552, 2013/4962 }\end{array}$ \\
\hline $\begin{array}{l}\text { KVK Yabancı Ulaş. } \\
\text { Kur. vergi oranı }\end{array}$ & KVK md.32 & 2 ADET; 2009/15022, 2013/4962 \\
\hline $\begin{array}{l}\text { KVK İnd. Kurum. } \\
\text { Vergisi oranı }\end{array}$ & KVK md.32/A & 0 ADET \\
\hline Nispet & $\begin{array}{l}\text { 6802 Gider } \\
\text { Vergileri K. Ek } \\
\text { Tablo }\end{array}$ & 6 ADET; 8/2823, 8/3415, 8/4395, 83/6310, 84/8063, 84/8426, \\
\hline SSDF Nispeti & $\begin{array}{l}3238 \text { Saylı SSDF } \\
\text { H. Kan. md.13 }\end{array}$ & 4 ADET; 85/10182, 86/10971, 87/12468, 96/8559 \\
\hline ATV Nispet & $\begin{array}{l}\text { Akaryakıt } \\
\text { Tüketim Vergisi } \\
\text { md.4 }\end{array}$ & $\begin{array}{l}\text { 13 ADET; 88/12814, 88/13356, 90/163, 90/917, 90/1190, 94/5795, } \\
\text { 94/6414, 95/7688, 97/9577, 98/10961, 98/11161, 98/11329, 2000/5 }\end{array}$ \\
\hline Nispet & $\begin{array}{l}\text { Taşıt Alım Vergisi } \\
\text { Kanunu }\end{array}$ & $\begin{array}{l}\text { 11 ADET; 88/13037, 94/5729, 94/6069, 94/6301, 95/7604, 96/8485, } \\
\text { 97/9131, 97/9428, 99/12894, 99/13329, 2002/3004, }\end{array}$ \\
\hline Nispet & Harçlar Kanunu & 3 ADET; 94/5536, 99/13644, 2000/1696 \\
\hline
\end{tabular}

Kaynak: Tablo 1980-1997 yılları arası için Maliye Bakanlığı GGM, 1997'den, 1997-2002 yılları arası için Maliye Bakanlığı GGM, 2002'den ve diğer yıllar için Kazancı Mevzuat Bilgi Bankasından yararlanılarak tarafımızca hazırlanmıştır.

Yukarıdaki tablodan da görüldüğü gibi beş maddedeki bu yetki hiç kullanılmamıştır. Diğer yedi maddedeki yetki 2 defa, iki maddedeki yetki 3 defa, üç maddedeki yetki 4 defa ve birer maddedeki yetki sırasıyla 5, 6 ve 7 defa kullanılmıştır. Ayrıca iki maddedeki yetki 9 defa, birer maddedeki yetki sırasıyla 11, 13, 17, 22, 23, 35, 60, 86 ve 101 defa kullanılmıştır.

Oranlardaki değişiklik en çok ÖTV kanununda yapılmıştır. Ancak bu değişikliklerin birçoğu Anayasada belirtilen oran unsuru dışında maktu tutarları veya matrahı belirleyecek şekilde de kullanıldığından sık sık tartışma konusu olmaktadır. Katma değer vergisindeki değişiklikler ise I ve II. Sayılı Listeye dahil olan malları belirlemek için kullanılmaktadır. Gelir ve kurumlar vergisindeki değişiklikler ise stopaj oranlarını yeniden belirlemek için kullanılmaktadır.

\subsection{Bakanlar Kurulunun Maktu Tutar İle Illgili Kararları}

Anayasanın 73/4. maddesinde sayılmamasına rağmen "maktu tutarlar" ile ilgili 15 kanunun 32 maddesinde Bakanlar Kuruluna yetki verilmiştir. Bakanlar Kuruluna verilen bu yetkinin konusu, kanun maddeleri ve kullanılan BKK sayısı aşağıda Tablo 6'da gösterilmiştir.

Tablo 6. "Maktu Tutar" ile ilgili Bakanlar Kuruluna Verilen Değişiklik Yapma Yetkisinin Dağılımı

\begin{tabular}{|l|l|l|}
\hline \multicolumn{1}{|c|}{ Konusu } & \multicolumn{1}{|c|}{ Kanun Maddesi } & \multicolumn{1}{c|}{ BKK Sayısı ve Numarası } \\
\hline Tecil Tutarı & AATUHK md. 48 & 0 ADET \\
\hline Tahsil İmkansızlığı & AATUHK md. 106 & 3 ADET; 97/10348, 99/13326, 2004/8267 \\
\hline $\begin{array}{l}\text { Özel İletişim Vergisi } \\
\text { tutarı }\end{array}$ & ÖiVK md. 39 & 0 ADET \\
\hline KKEG tutarı & GVK md. 41 & 0 ADET \\
\hline
\end{tabular}




\begin{tabular}{|c|c|c|}
\hline $\begin{array}{l}\text { Zirai işletme büyüklüğü } \\
\text { ölçüsü }\end{array}$ & GVK md. 54 & $\begin{array}{l}8 \text { ADET; 8/2309, 8/4321, 85/9031, 86/10499, 88/12646, } \\
91 / 1440,94 / 5336,98 / 12095\end{array}$ \\
\hline Götürü Usul - Basit Usul & GVK md. 51 & $\begin{array}{l}\text { 11 ADET; 8/5521, 92/2683, 93/5142, 94/5230, 95/6595, } \\
95 / 6430,96 / 7843,96 / 8005,97 / 9516,98 / 10885,2000 / 1591 \text {, }\end{array}$ \\
\hline $\begin{array}{l}\text { Talih Oyunları Salonları } \\
\text { Kazancı Asgari Vergi }\end{array}$ & GVK mük.md. 111 & 3 ADET; 95/7593, 96/8955, 97/10351 \\
\hline Hayat Standardı Tutarı & GVK mük.md. 116 & 3 ADET; 83/7548, 84/8836, 86/11306 \\
\hline $\begin{array}{l}\text { Gelir Vergisi Maktu Had } \\
\text { ve Tutarlar (Eski) }\end{array}$ & GVK md.13,46,53 & $\begin{array}{l}14 \text { ADET; 8/5860, 83/7518, 83/7547, 85/10172, 86/11307, } \\
87 / 12467,88 / 13642,89 / 14913,91 / 2569,92 / 3892,93 / 5146 \text {, } \\
94 / 6300,95 / 7593,97 / 10351\end{array}$ \\
\hline $\begin{array}{l}\text { GVK Maktu Had } \\
\text { Tutarları }\end{array}$ & GVK mük. md. 123 & $\begin{array}{l}13 \text { ADET; } 83 / 7511,92 / 3892,93 / 5146,94 / 6300,95 / 7593 \\
\text { 96/8955, } 97 / 10351,2000 / 1689,2001 / 3398,2002 / 5000 \\
2003 / 6578,2004 / 8295,2005 / 9826\end{array}$ \\
\hline $\begin{array}{l}\text { Maktu Defter Tutma } \\
\text { Hadleri }\end{array}$ & VUK md. 177 & $\begin{array}{l}11 \text { ADET; 8/5946, 83/7510, 88/13603, 89/14921, 90/1281, } \\
\text { 92/3898, 93/5107, 94/6295, 95/7588, 96/8954, 97/10346, }\end{array}$ \\
\hline $\begin{array}{l}\text { Defteri Yabancı Dilde } \\
\text { Tutma Had ve Tutar }\end{array}$ & VUK md. 215 & 0 ADET \\
\hline $\begin{array}{l}\text { VUK Maktu Had ve } \\
\text { Tutarlar }\end{array}$ & VUK mük.md. 414 & $\begin{array}{l}15 \text { ADET; 89/14155, 89/14439, 89/14918, 91/1856, } \\
\text { 91/2567, 92/2924, 92/3894, 93/5144, 94/6296, 95/7595, } \\
97 / 10345,98 / 12044,2000 / 1697,2001 / 3395,2002 / 4983,\end{array}$ \\
\hline MTV Vergi Miktarı & MTVK md. 10 & $\begin{array}{l}12 \text { ADET; 85/9752, 86/11304, 87/12465, 88/13038, } \\
88 / 13645,89 / 14912,90 / 1317,91 / 2568,92 / 3920 \\
2000 / 1699,2001 / 3397,2009 / 15725\end{array}$ \\
\hline $\begin{array}{l}\text { DVK Maktu Had ve } \\
\text { Tutarlar }\end{array}$ & DVK mük.md. 30 & 4 ADET; 85/10173, 87/12466, 88/13599, 89/14914, \\
\hline $\begin{array}{l}\text { Harçlar Kanunu Maktu } \\
\text { Had ve Tutarlar }\end{array}$ & $\begin{array}{l}\text { HK md.96, } \\
\text { mük.md.138 }\end{array}$ & $\begin{array}{l}16 \text { ADET; 83/7539, 85/10177, 87/12462, 88/12514, } \\
\text { 88/13600, 89/14920, 92/3899, 99/13644, 2000/866, } \\
\text { 2009/14813, 2009/15725, 2010/512, 2011/2628, } \\
2012 / 3735,2012 / 4116,2016 / 9641\end{array}$ \\
\hline EVK Vergi Değeri & EVK md.29 & 3 ADET; 2000/1694, 2011/2628, 2016/9641 \\
\hline Maktu Vergi ve Harçlar & $\begin{array}{l}\text { BGK md. 15, 21, 64, } \\
74,77\end{array}$ & 2 ADET; 92/3278, 2005/8730 \\
\hline $\begin{array}{l}\text { Çevre Temizlik Vergisi } \\
\text { Bina Grupları ve Tutarlar }\end{array}$ & BGK mük.md. 44 & 2 ADET; 93/5105, 2005/9817 \\
\hline $\begin{array}{l}\text { Büyük Yatırımlarda lade } \\
\text { Tutarı }\end{array}$ & KDVK geç.md. 30 & 0 ADET \\
\hline $\begin{array}{l}\text { KDV'de Vergi İndirimi } \\
\text { Sınırı }\end{array}$ & KDVK md.29 & $\begin{array}{l}11 \text { ADET; } 1984 / 8837,2000 / 1074,2001 / 2185,2002 / 3606, \\
\text { 2006/10379, 2008/13903, 2009/14802, 2009/14812, } \\
\text { 2009/14881, 2009/15081, 2009/15315 }\end{array}$ \\
\hline Vergi Tutarı & $\begin{array}{l}\text { Akaryakıt Tüketim } \\
\text { Vergisi Kanunu md. } 96\end{array}$ & $\begin{array}{l}49 \text { ADET; 8/4056, 85/10037, 2000/252, 2000/282, } \\
\text { 2000/304, 2000/333, 2000/427, 2000/461, 2000/541, } \\
\text { 2000/676, 2000/678, 2000/680, 2000/683, 2000/709, } \\
\text { 2000/728, 2000/869, 2000/872, 2000/977, 2000/978, } \\
\text { 2000/1026, 2000/1041, 2000/1165, 2000/1215, 2000/1220, } \\
\text { 2000/1274, 2000/1306, 2000/1311, 2000/1468, 2000/1689, } \\
2000 / 1798,2001 / 1890,2001 / 1928,2001 / 1961,2001 / 2067, \\
2001 / 2201,2001 / 2308,2001 / 2382,2001 / 2582,2001 / 2716, \\
2001 / 3039,2001 / 3272,2001 / 3510,2002 / 3592,2002 / 3788, \\
2002 / 3911,2002 / 4035,2002 / 4195,2002 / 4393,2002 / 4565\end{array}$ \\
\hline Miktar & $\begin{array}{l}\text { Taşıt Alım Vergisi } \\
\text { Kanunu }\end{array}$ & $\begin{array}{l}9 \text { ADET; 85/10176, 86/11305, 87/12463, 88/13640, 90/291, } \\
\text { 90/1321, 91/2566, 92/3921, 2000/1692 }\end{array}$ \\
\hline Tutar & Özel İşlem Vergisi & 3 ADET; $2000 / 1691,2001 / 3439,2003 / 5751$ \\
\hline SSDF Miktarı & $\begin{array}{l}3238 \text { Sayılı SSDF } \\
\text { Hakkında Kanun md.1 }\end{array}$ & 2 ADET; 87/12219, 95/7200 \\
\hline Miktar & $\begin{array}{l}\text { Gençlik, Spor ve Sağlık } \\
\text { Hizm. Ver. }\end{array}$ & 2 ADET; 85/7619, 99/12481 \\
\hline
\end{tabular}

Kaynak: Tablo 1980-1997 yılları arası için Maliye Bakanlığı GGM, 1997'den, 1997-2002 yılları arası için Maliye Bakanlığı GGM, 2002'den ve diğer yıllar için Kazancı Mevzuat Bilgi Bankasından yararlanılarak tarafımızca hazırlanmıştır. 
Yukarıdaki tablodan da görüldüğü gibi beş maddedeki bu yetki hiç kullanılmamıştır. Dört maddedeki yetki 2 defa, beş maddedeki yetki 3 defa, iki maddedeki yetki 11 defa, birer maddedeki yetki ise sırasıyla 4, 8, 9, 12,13, 14, 15, 16 ve 49 defa kullanılmıştır. Ülkemizde enflasyonun düştüğü 2000 yılından sonra maktu tutarlarda Bakanlar Kurulunun değişiklik yapma yetkisinin çok fazla veya sık kullanıldığı söylenemez. Son yıllarda maktu tutarlarda güncelleme yapmak amacıyla daha çok yeniden değerleme oranının kullanılması daha doğrudur. Nitekim Anayasa Mahkemesi, Bakanlar Kurulu tarafından düzenleme yapma yetkisinin kullanılmasının enflasyonun yaratmış olduğu yıpranmayı telafi etmeye yönelikse, genellikle Anayasa'nın 73. maddesinin 4. fıkrasındaki düzenlemenin amacına aykırı olmadığı yönünde görüş bildirmekle birlikte, bu konuda keyfi uygulamalara yol açmamak için "yeniden değerleme oranı"nın kullanılmasının daha objektif olduğunu vurgulamaktadır (AYM, E:1996/75, K:1997/50). Bu nedenle, vergi tutarlarının maktu olarak belirlendiği kanunlarda Bakanlar Kuruluna yetki verilmesi yerine "yeniden değerleme oranı" ile güncelleme yoluna gidilmesi daha isabetli bir düzenlemedir.

\subsection{Bakanlar Kurulunun Diğer Konular ille ilgili Kararları}

Anayasanın 73/4. maddesinde sayılmamasına rağmen "diğer konular" ile ilgili 13 kanunun 19 maddesinde Bakanlar Kuruluna yetki verilmiştir. Bakanlar Kuruluna verilen bu yetkinin konusu, kanun maddeleri ve kullanılan BKK sayısı aşağıda Tablo 7'de gösterilmiştir.

Tablo 7. Diğer Konular ile ilgili Bakanlar Kuruluna Verilen Değişiklik Yapma Yetkisinin Dağılımı

\begin{tabular}{|c|c|c|}
\hline Konusu & Kanun Maddesi & BKK Sayısı ve Numarası \\
\hline Geçici Vergi Dönemi belirleme & GVK mük. md. 120 & 2 ADET; 2000/329, 2000/1514 \\
\hline Beyan süresi uzatımı & GVK geç. md. 85 & 1 ADET; 2013/5174 \\
\hline Vergi Sorumlusunu belirleme & VUK md. 11 & 0 ADET \\
\hline $\begin{array}{l}\text { Emlak vergisine ait bedel ve } \\
\text { değ. tespiti süresi }\end{array}$ & VUK mük. md. 49 & 0 ADET \\
\hline Emlak Vergisi Mevzu & EVK md.12 & 2 ADET; 83/6122, 2002/5077 \\
\hline Beyan dönemi değişikliği & EVK, md. 23 & 2 ADET; 8/4317, 85/9575 \\
\hline $\begin{array}{l}\text { Harcamalara katılma payı } \\
\text { ödeme süresi }\end{array}$ & BGK md. 93 & 0 ADET \\
\hline Dahilde işleme rejimi kapsamı & KDVK geç.md.17 & 0 ADET \\
\hline $\begin{array}{l}\text { ÖTV'nin tecil edilecek kısmı ve } \\
\text { süresi }\end{array}$ & ÖTV md. 8 & $\begin{array}{l}7 \text { ADET; 2002/4481, 2005/8392, 2008/13835, } \\
\text { 2008/14061, 2010/668, 2011/2198, 2012/3792 }\end{array}$ \\
\hline $\begin{array}{l}\text { ÖTV Vergileme ölçüleri ve } \\
\text { matrah }\end{array}$ & ÖTV md. 11 & $\begin{array}{l}6 \text { ADET; 2005/8392, 2008/13762, 2009/15200, } \\
\text { 2009/15725, 2011/1435, 2012/3735 }\end{array}$ \\
\hline $\begin{array}{l}\text { ÖTV Vergilendirme dönemi ve } \\
\text { ödeme süresi }\end{array}$ & ÖTV md. 14 & 0 ADET \\
\hline $\begin{array}{l}\text { KVK Sınai mülkiyet haklarında } \\
\text { istisnası süresi }\end{array}$ & $2016 \mathrm{KVK}$ md.5/B & 0 ADET \\
\hline Kapsam & $\begin{array}{l}\text { Ücretlerde vergi iadesi } \\
\text { kanunu }\end{array}$ & $\begin{array}{l}16 \text { ADET; 84/7777, 84/7791, 84/7923, 84/8108, } \\
\text { 84/8791, 84/8854, 85/9070, 85/9205, 85/10181, } \\
\text { 88/13382, 88/13641, 89/14387, 90/1183, 91/2113, } \\
91 / 2278,94 / 5372\end{array}$ \\
\hline Tavan Fiyat & $\begin{array}{l}\text { Akaryakıt Fiyat İstikrar } \\
\text { Fonu }\end{array}$ & 2 ADET; 2001/2068, 2001/2134 \\
\hline
\end{tabular}


A. Gerçek \& F. Bakar / Anayasa'nın 73/4. Maddesi ile Bakanlar Kuruluna Yetki Verilmesi

\begin{tabular}{|l|l|l|}
\hline Süre Uzatımı & $\begin{array}{l}\text { Akaryakıt Tüketim } \\
\text { Vergisi }\end{array}$ & 1 ADET; 2001/1890 \\
\hline Terkin & AATUHK & 3 ADET; 92/3573, 93/4899, 2003/5228 \\
\hline Tecil & AATUHK & 3 ADET; 97/9792, 97/9969, 98/10833 \\
\hline Yurtdışı çıkış harcı kapsamı & $\begin{array}{l}\text { Yurtdışı çııı̧ harcı } \\
\text { kanunu }\end{array}$ & 2 ADET; 2002/3545, 2001/2762 \\
\hline Taksit ödeme süresi & 6111 Sayılı Kanun & 1 ADET; 2011/1713 \\
\hline
\end{tabular}

Kaynak: Tablo 1980-1997 yılları arası için Maliye Bakanlığı GGM, 1997'den, 1997-2002 yılları arası için Maliye Bakanlığı GGM, 2002'den ve diğer yıllar için Kazancı Mevzuat Bilgi Bankasından yararlanılarak tarafımızca hazırlanmıştır.

Yukarıdaki tablodan da görüldüğü gibi altı maddedeki bu yetki hiç kullanılmamıştır. Üç maddedeki yetki 1 defa, beş maddedeki yetki 2 defa, iki maddedeki yetki 3 defa, birer maddedeki yetki ise sırasıyla 6, 7 ve 16 defa kullanılmıştır.

Anayasanın 73/4. maddesi ile Bakanlar Kurulunun değişiklik yapma yetkisi verginin bazı unsurları ile sınırlı tutulmasına rağmen, belirlenen kapsamın dışında kalan birçok konuyla ilgili yetki devri ile ilgili düzenlemelere yer verilmiştir. Ancak yukarıda belirtilen konularla ilgili verilen yetkiler Anayasada sayılan unsurlar ve sınırların dışına çıktığından, kullanılan bu yetkiler Anayasaya açıkça aykırılık oluşturmaktadır.

\section{Vergileme Alanında Bakanlar Kuruluna Yetki Verilmesinin Gerekliliği}

Anayasa'nın 73/4. maddesindeki "Vergi, resim, harç ve benzeri malî yükümlülüklerin muaflık, istisnalar ve indirimleriyle oranlarına ilişkin hükümlerinde kanunun belirttiği yukarı ve aşağı sınırlar içinde değişiklik yapmak yetkisi Bakanlar Kuruluna verilebilir" hükmü ile vergilemede kanunilik ilkesinin istisnası olan bir alan yaratılmıştır. Bu hükme yer verilmesinin gerekçesi; "vergi yükünün muaflığı ve istisnaların zamanla artan oranla düşmesini engellemek" (Danışma Meclisi, 2011: 145) ve "ekonomiye etkin ve hızlı müdahale edebilmek için esneklik ve çabukluk getirmek" (Palamut, 2002: 223) şeklinde belirtilmiştir. 1970'lerin yüksek enflasyon koşulları altında Bakanlar Kurulu'na böyle bir yetki devri belli ölçüde anlayışla karşılanabilir. Ülkemizde yüksek enflasyon koşulların 2000'li yılların başına kadar devam ettiği söylenebilir. Ancak 2003 yılından sonra ülkemizde yüksek enflasyon dönemi sona ermiş ve buna bağlı olarak da ekonomiye bu gerekçe ile etkin ve hızlı müdahale gerekliliği bir argüman olmaktan çıkmıştır.

Vergilendirme yetkisinin belirli kişi ve gruptan alınıp halkın seçtiği temsilcilerden oluşan yasama organına verilmesi devlete olan güven ve sadakatin, hukuki güvenlik ve istikrarın bir işaretidir. Bunun sağlanması ise ancak yasama organı tarafından kabul edilecek kanunlarla mümkündür. Vergilemede kanunilik ilkesi bu zaruretin sonucunda ortaya çıkmış ve böylece vergilendirmenin esasına ilişkin konularda gerek yürütme organına, gerekse yargı organına düzenleme yetkisi verilmemesi benimsenmiştir (Karakoç, 1995: 18).

Ancak 1971 yılı değişiklikleriyle başlayan yürütmenin güçlendirilmesi eğilimini 1982 Anayasasında çok daha belirgin hale gelmiştir. Güçlü devlet için hak ve 
özgürlükleri sınırlayıcı düzenlemeler yapan güçlü yürütme yaratılmıştır (Bakırcı, 2017: 43). Bunun bir parçası olarak verginin temel unsurları üzerinde etkili (muaflık, istisna, indirim ve oran) bazı unsurlarda ve kanunla belirlenen alt ve üst sınırlar arasında düzenleme yapma yetkisi Bakanlar Kuruluna verilmiştir. Kapsamı ve kullanımı yukarıda da gösterildiği üzere, Bakanlar Kuruluna verilen bu yetkinin büyük bir bölümü mevcut tutar ve oranların artırılmasına yöneliktir. Ancak Bakanlar Kuruluna Anayasada belirtilen sınırların dışında kalan birçok konuda da değişiklik yapma yetkisi verildiği görülmektedir. Bu durum ise bu konularda yapılan düzenlemelerin TBMM'nin bilgi ve onayı dışında kalmasına, Anayasa Mahkemesinin denetiminden uzak ve idari yargının çok sınırlı denetimine tabi tutulmasına yol açmaktadır (Duran, 1986: 16). Burada esas sorun Bakanlar Kuruluna tanınan yetkinin ekonomik konjonktürle örtüşmeyecek şekilde sınırsız olabilmesindedir. Nitekim Anayasa Mahkemesi'nin bir kararında “... Bakanlar Kurulu, yasanın belirttiği alt ve üst sınırlar içinde değişiklik yapabilecek, ancak bu sınırları aşacak biçimde herhangi bir düzenleme getiremeyecektir. Bakanlar Kurulu'na verilen bu yetki istisnai bir yetkidir. Vergilendirmede esas kural, vergilerin kanunla konulup, kaldırılması ve değiştirilmesidir. Nitekim 73. maddenin son fıkrasına ilişkin gerekçede vergi yükünün muaflığı ve istisnaların zamanla artan oranla düşmesini engellemek üzere kanunla Bakanlar Kurulu'na yetki verilmesinin kabul edildiği belirtilmiştir. Ancak Bakanlar Kurulu'na tanınan yetkinin çok geniş olması, verginin yasallığı ilkesinin zedelenmesine yol açarak yasama yetkisinin yürütme organına devri sonucunu doğurabileceğinden kabul edilemez" denilerek Motorlu Taşıtlar Vergisi Kanunu'nun 10. maddesinin üçüncü fıkrasının (b) bendi ile Bakanlar Kuruluna verilen "vergi miktarını yirmi katına kadar artırma" yetkisine ilişkin kanun düzenlemesini iptal etmiştir (AYM, E: 2001/36, K: 2003/3). Çünkü Bakanlar Kuruluna yetki verilmesi ile ilgili bu tür düzenlemelerin artması "vergilemede kanunilik ilkesi"ni zedelemekte ve vergilerin kararlarla konulmasına yol açmaktadır (Karakoç, 1995: 19).

Diğer taraftan vergilemede belirlilik ilkesi, vergi kanunları ile getirilen hükümlerin ilgili kişilerin yapacakları bir işlemin ne tür sonuçlar doğurabileceğini öngörmelerini mümkün kılacak şekilde düzenlenmesini gerektirir (AYM, E:2010/7, K:2011/172). "Öngörülebilirlik Şartı" olarak nitelendirilen bu ilkeye göre, kanunların uygulanmasında takdirin kapsamı ve uygulama yöntemi bireyleri keyfi ve öngörebilecekleri müdahalelerden koruyacak düzeyde açıklıkta yazılmalıdır. Belirlilik ilkesi hukuki güvenlikle bağlantılı olup, buna göre birey, kanundan belirli bir kesinlik içinde, hangi somut eylem ve olguya hangi hukuksal yaptırımın veya sonucun bağlandığını, bunların idareye hangi müdahale yetkisi verdiğini öngörebilmesini zorunlu kılar (AYM, E:2011/6, K:2012/16). Bu nedenle Bakanlar Kuruluna düzenleme yapma yetkisinin verilmesinin "vergilemede kanunilik ilkesi"ni zedelediği yorumunu, bu kararların "vergilemede belirlilik ilkesi"ne de zarar verdiği şeklinde genişletmek mümkündür (Kelecioğlu, 2001: 165). Çünkü 1980-2017 yılları arasında vergilendirme ile ilgili 735 adet Bakanlar Kurulu Kararının çıkarıldığı ve bunlardan bazıları ile birden fazla kanun maddesi ile ilgili düzenleme yapıldığı dikkate alındığında; mükelleflerin neredeyse ayda iki defa yeni bir değişiklikle karşı karşıya kaldıkları söylenebilir. Böyle bir ortamda da mükelleflerin vergilendirme ile ilgili durumlarını öngörmeleri mümkün değildir. 
Demokrasiyi ve hukukun üstünlüğünü benimsemiş bir ülkede "kanunsuz vergi olmaz" ve "temsilsiz vergi olmaz" temel ilkelerinden sapmalara yol açabilecek hiçbir hükmün kabul edilmesi düşünülemez. Başka ülke anayasalarında Bakanlar Kuruluna doğrudan yetki veren düzenlemelere rastlanmamasına karşılık (Saban, 2012), ülkemizde Bakanlar Kurulu'na vergi konusunda devredilen yetkiler, hiçbir ülkede bulunmayan kapsam ve genişliktedir. Bu nedenle ekonomik istikrarın sağlandığı ve enflasyonun makul seviyelerde olduğu günümüzde, ekonomiye etkin ve çabuk müdahale edebilme ihtiyacından ziyade, vergilemede kanunilik, hukuki güvenlik ve belirlilik ilkelerinin ön planda tutulması esas olmalıdır. Dolayısıyla ülkemizde çağdaş hukuk devleti anlayışının egemen kılınabilmesi için vergilemede kanunilik ilkesini zedeleyen, vergilemede istikrar ve belirliliği ortadan kaldıran Bakanlar Kurulu'na değişiklik yapma yetkisi verilmesi ile ilgili hüküm Anayasa metninden çıkarılmalıdır (Bkz. Batırel, 2011: 25; Savaş, 1994: 219).

\section{Sonuç}

Vergileme ilkelerinin anayasal norm olarak somutlaşması, ülkelerin demokratikleşme sürecine paralel olarak uzun mücadeleler sonucunda gerçekleşebilmiştir. Vergilemenin temelini oluşturan "kanunsuz vergi olmaz" ve "temsilsiz vergi olmaz" prensiplerine uygun olarak çağdaş demokratik ülke anayasalarının tamamında kanunilik ilkesi açıkça düzenlenmiştir. Buna karşılık incelenen ülke anayasasında başkana, hükümete veya Bakanlar Kuruluna vergilendirme yetkisinin herhangi bir şekilde devrine ilişkin bir hüküm bulunmamaktadır. Anayasalardaki bu genel kurala karşılık ülkemizde enflasyonun yaratmış olduğu aşınmayı telafi etmek ve ekonomiye hızlı ve etkin bir şekilde müdahale etmek amacıyla Bakanlar Kuruluna böyle bir yetki verilmiştir.

Bakanlar Kuruluna verilen değişiklik yapma yetkisi verginin muaflık, istisna, indirim ve oranlarını kapsamakta olup, 1971-2017 döneminde vergi kanunlarının toplam 107 maddesinde Bakanlar Kuruluna yetki devrine ilişkin hüküm bulunmaktadır. Ancak bu maddelerin 25'inde Bakanlar Kuruluna verilen yetki şu ana kadar hiç kullanılmamıştır. Bakanlar Kuruluna verilen değişiklik yapma yetkisi; sırasıyla muaflık unsurunda 10 defa, istisna unsurunda 22 defa, indirim unsurunda 36 defa, oran unsurunda 438 defa, maktu tutarlarda 195 defa ve diğer konularda 48 defa kullanılmıştır. Buna göre Bakanlar Kuruluna verilen değişiklik yapma yetkisi en az muaflık unsurunda, en fazla ise oran unsurunda kullanılmıştır. Oranlardaki değişiklik de en çok ÖTV kanununda yapılmıştır. Ancak bu değişikliklerin çoğu Anayasada belirtilen oran unsuru dışında maktu tutarları veya matrahı belirleyecek şekilde kullanıldığından sık sık tartışma ve iptal davalarına konu olmaktadır.

Ülkemizde 2003 yılından sonra enflasyonun düşmesiyle birlikte Bakanlar Kuruluna yetki devrine yol açacak yeni düzenlemelerin sayısında azalma olması beklenirken, uygulamada böyle olmamış ve 32 tane yeni kanun maddesinde düzenleme yapma yetkisinin Bakanlar Kuruluna verildiği görülmüştür. Bu durum da ülkemizde "vergilemede kanunilik ilkesi" yerine vergilerin kararlarla konulması eğiliminin aynen devam ettiğini göstermektedir. Diğer taraftan 1980-2017 döneminde 
vergilendirme ile ilgili 735 adet Bakanlar Kurulu Kararının çıkarıldığı ve neredeyse ayda iki defa yeni bir değişiklik yapıldığı dikkate alındığında Bakanlar Kuruluna yetki devrinin "vergilemede belirlilik ilkesi"ne de zarar verdiğini ortaya koymaktadır. Bu nedenle ülkemizde hukuk devleti ve vergilemede kanunilik ilkesini zedeleyen, vergilemede istikrar ve belirliliği ortadan kaldıran Bakanlar Kuruluna yetki verilmesi ile ilgili hüküm Anayasa metninden çıkarılmalıdır.

\section{Kaynakça}

Bakırcı, F. (2017). "Yasama Sürecinin Hızlandırılması - Yasama Yetkisinin Devri ve Nedenleri Üzerine", Kamu Hukukun Dönüşümü, 29-30 Nisan 2017, Galatasaray Üniversitesi, İstanbul, http://www.kamuhukukculari.org/upload/dosyalar/Yasama_SuOrecinin_ Hzlandrlmas_-_Yasama_Yetkisinin_Devri_ve_Nedenleri_UOzerine.pdf, (05.05.2017).

Batırel, Ö. F. (2011). "Anayasalarda Vergi Hakkı ve Ödevi, AB Uygulaması ve Türkiye”, i̇stanbul Ticaret Üniversitesi Sosyal Bilimler Dergisi, Yıl 10, S. 2, ss. 13-25.

CTPG (Utrecht University Centre for Taxation and Public Governance), (2006). Constitutional Effects On The Tax System, Netherlands.

Çağan, N. (1982). Vergilendirme Yetkisi, İstanbul: Kazancı Hukuk Yayınları.

Danışma Meclisi (2011). Türkiye Cumhuriyeti Anayasası Madde Gerekçeli, Ankara, TBMM, https://yenianayasa.tbmm.gov.tr/docs/gerekceli_1982_anayasasi.pdf, (10.02.2017).

Duran, L. (1986). "Anayasa Mahkemesine Göre Türkiye'nin Hukuk Düzeni”, Amme İdaresi Dergisi, Cilt 19, Sayı 1, Mart 1986, http://www.todaie.edu.tr/resimler/ekler/ 3a31e01a48ae7f5_ek.pdf?dergi=Amme\%20ldaresi\%20Dergisi, (20.04.2017).

Gerçek, A. (2006). Türk Vergi Hukukunda Idarenin Takdir Yetkisi, Ankara, Yaklaşım Yayıncılık.

Gerçek, A., Bakar, F., Mercimek, F., Çakır, E.U. \& Asa, S. (2014). "Vergilemenin Anayasal Temellerinin Çeşitli Ülkeler Açısından Karşılaştırılması ve Türkiye İ̧̧in Çıkarımlar", Ankara Üniversitesi Hukuk Fakültesi Dergisi, Cilt 63, No 1, ss. 81-130.

Güneş, G. (2008). Verginin Yasallığı Ilkesi, 2. baskı, İstanbul, XII Levha Yayıncılık.

Kaneti, S. (1989). Vergi Hukuku, 2. baskı, İstanbul, Filiz Kitabevi.

Kaneti, S. (2011). "Türk Vergi Hukukunun Anayasal Temelleri”, Makaleler, İstanbul: XII Levha.

Karakoç, Y. (1995). Sosyal Maliye, İzmir, Dokuz Eylül Üniversitesi Hukuk Fakültesi Döner Sermaye İşletmesi Yayınları.

Kelecioğlu, M. A. (2001). “Vergi Kanunları Ille Bakanlar Kuruluna Tanınan Yetkilerin Vergilemede Kanunilik ve Belirlilik Illkeleri Çerçevesinde İrdelenmesi", Yaklaşım, Yıl 9, S. 105, (Eylül 2001), ss. 159-166.

Kumrulu, A. G. (1979). "Vergi Hukukunun Bir Kısım Anayasal Temelleri" Ankara Üniversitesi Hukuk Fakültesi Dergisi, Cilt 36, No 1-4, ss. 147-162.

Maliye Bakanlığı Gelirler Genel Müdürlüğü (1997). Vergi Mevzuatı Ile ilgili Bakanlar Kurulu Kararları (1980-1997), Ankara.

Maliye Bakanlığı Gelirler Genel Müdürlüğü (2002). Vergi Mevzuatı ile ilgili Kanunlar ve Bakanlar Kurulu Kararları (1997-2002), Ankara. 
Munday, R. (2003). "İngiliz Hukukunda ve Common Law Ülkelerinde Kanunilik İlkesi”, (Çev: Z. T. Kangal), İstanbul Üniversitesi Hukuk Fakültesi Mecmuası, Cilt 61, No 1-2, 2003, ss. 441464.

Öncel, M., Kumrulu, A. \& Çağan, N. (2010). Vergi Hukuku, 18. baskı, Ankara, Turhan Kitabevi.

Öz, E. (2004). Vergilendirmede Kanunilik ve Türk Vergi Sistemi, Ankara, Gazi Kitabevi.

Özer, i. (1977). Vergileme Illkeleri ve Türk Vergi Sistemi, Ankara, Türkiye ve Orta Doğu Amme Idaresi Enstitüsü Yayınları.

Palamut, M. E. (2002). "Ulusal Egemenlik Bağlamında Vergilendirme Yetkisi ve Türkiye'nin AB Karşısındaki Konumu", 17. Türkiye Maliye Sempozyumu: Avrupa Birliğine Geçiş Süreci ve Türk Kamu Maliyesinin Uyumu, Ankara, TÜRMOB Yayınları No 185, ss. 219-245.

Saban, N. (2012). "Anayasa Tartışmalarında Vergi Ödevi”, http://www.vmhk.org.tr/ ?p=3576, (05.03.2017).

Savaş, V. F. (1994). "Yeni Anayasa İçin Ekonomik Anayasa Önerileri", Anayasa Yargııı Dergisi, C. 11 , ss. 215-226.

Saygılıoğlu, N. (1987). Vergi Hukukunda Yorum, Ankara, Maliye ve Gümrük Bakanlığı APKK Yayını No: 1987/288.

Şenyüz, D. (1999). "Tevkifat Kapsamının Bakanlar Kurulu Kararları ile Belirlenmesinin Yatırım İndirimi Açısından Değerlendirilmesi", Yaklaşım, Yıl 7, S. 83, (Kasım 1999), ss. 19-24.

Tavşancı, A. (2010). "Yerel Yönetimlerin Vergilendirme Yetkisi", Mahalli idareler Maliyesi Üzerine Yazılar, (Ed. Figen Altuğ, Özhan Çetinkaya, Selçuk Ipek), Bursa, Ekin Basım Yayın Dağıtım, 2010, ss. 63-96.

Thuronyi, V. (2003). Comparative Tax Law, The Netherlands: Kluwer Law International.

Tuncer, S. (2003). Vergi Usul Kanunu ve Uygulaması, Ankara, Yaklaşım Yayınları.

Yaltı, B. (2011). “Anayasa Mahkemesi'nin Vergi Konulu Kararları Bakımından Geriye Yürümezlik Esası: Ex Tunc-Ex Nunc-Pro Futuro Etki Üzerine Değerlendirmeler", Vergi Hukukunda Geriye Yürümezlik Esası, Uluslararası Vergi Hukuku Konferansları Serisi-1, (Ed: Billur Yaltı), İstanbul, Beta Basım, 2011, ss. 173-208.

AYM, E:1996/75, K:1997/50, T:14.05.1997, http://kararlaryeni.anayasa.gov.tr/Karar/Content/ 82974a0b-6db0-4462-8466-b1377e2b5552?excludeGerekce=False\&wordsOnly=False, (13.04.2007).

AYM, E:2001/36, K:2003/3, T:16.01.2003, http://kararlaryeni.anayasa.gov.tr/Karar/Content/ 737a7709-a02b-4353-b74a-e160a5455344?excludeGerekce=False\&wordsOnly=False, (20.04.2007).

AYM, E:2010/7, K:2011/172, T:22.12.2011, http://kararlaryeni.anayasa.gov.tr/Karar/Content/ 9d8da8e0-af9e-4154-bd6f-d40dc94d217e?excludeGerekce=False\&wordsOnly=False, (22.04.2007).

AYM, E:2011/6, K:2012/16, T:26.01.2012, http://kararlaryeni.anayasa.gov.tr/Karar/Content/ de4c4ad5-1b7d-4ea0-95a3-d90d563dd8f2?excludeGerekce=False\&wordsOnly=False, (22.04.2007).

Kazancı Mevzuat Bilgi Bankası, http://www.kazanci.com/kho2/mbb/giris.htm. 